\title{
Improving Students' Critical-Thinking Skills Through Student Facilitator and Explaining Model in Momentum and Impulse Topic
}

\author{
Adam Malik $^{\text {a) }}$, Vitriani ${ }^{\text {b) }}$, M. Minan Chusnic ${ }^{\text {c) }}$ \\ Program Studi Pendidikan Fisika, UIN Sunan Gunung Djati Bandung \\ Jalan A.H. Nasuiton No.105 Cibiru, Bandung, Jawa Barat 40614
}

$\square:{ }^{a)}$ adammalik@uinsgd.ac.id, ${ }^{\text {b) }}$ vitriani2103@gmail.com, ${ }^{\mathrm{c})}$ minan.chusni@uinsgd.ac.id

\begin{abstract}
This study aims to determine the implementation of cooperative learning models using type Student Facilitator and Explaining (SFAE) and the improvement of students' critical-thinking skills in momentum and impulses topic. We use pre-experiment design, with the one-group pretest-posttest. The population of this study was class X MIA YAS Bandung with the sample of class X MIA 2 amounted to 30 students selected by random technique. We use the observation sheet as the instrument to observe the implementation of teacher and student activities during the cooperative learning model type SFAE. The essay tests are used to measure the improvement of students' critical-thinking skills. The results of the study showed that the implementation of teacher activities was $81 \%$ and student activities by $77 \%$ in the good category. Increasing students' critical-thinking skills is the medium category with an average normalized gain value of 0.63 . Based on the results of hypothesis testing using the paired sample t-test, it was obtained t-count (34.08) > t-table (2.052) which means that Ho was rejected and Ha was accepted. It was concluded that there was an increase in students' criticalthinking skills after applying the SFAE type cooperative learning model to the material of momentum and impulse. Thus, this learning model of type SFAE can be used to improve students' higher-order thinking skills.
\end{abstract}

Keywords: SFAE, critical-thinking skills, momentum and impulse

\section{INTRODUCTION}

The development of the 21 st century requires students to compete with other students, without being confined to the geographical boundaries of the country. According to Rotherham \& Williangham (2009) states that a student's success depends on fulfilling 21st-century skills, so students must learn to have it. The challenge for 21 st-century education is to educate students who live and work in environments that are rich in technology and information. Many universities prepare their students to fulfill competencies according to workplace demands (Malik et al. 2018a). The quality of human resources must have various abilities, including the skills of working together, thinking critically-creatively, understanding various cultures, mastering information technology, and being able to learn independently so that they can compete in filling the job market. Students need to be equipped with a variety of life skills, one of which is critical-thinking skills. Critical thinking includes some cognitive skills, and intellectual dispositions needed to identify, analyze, and evaluate arguments effectively to find solutions, can formulate and present convincing reasons in supporting 
conclusions and can make rational and appropriate decisions about what is done and believed (Bassam 2008).

Zohar (2013) said that critical-thinking skills would not develop well without any conscious effort to develop them during learning. Special exercises and treatments are needed as a solution so that critical-thinking skills can be achieved. Therefore, it is a challenge for teachers and students to find effective solutions or ways to develop critical-thinking skills. According to Trilling \& Fadel (2009) states that critical thinking and problem-solving skills can be learned through a variety of inquiry and problem-solving activities that are trained and developed effectively with meaningful project-based learning by giving questions and problems.

Critical thinking includes the knowledge of logical inquiry methods and reasoning according to Glaser in Gregor (2007). Helpern (2014) defines critical thinking as a cognitive skill or strategy to increase the probability of the desired outcome. This thinking is used to describe results that are purposeful, reasoned, and directed or directed. Critical-thinking skills can be trained and developed through classroom learning or laboratory activities (Malik et al. 2018b). So critical thinking is an active and structured process of thinking in understanding problems, gathering information, reasoning and arguing to make conclusions and determine decisions that can be trained and developed in classroom learning and lab activities in the laboratory. Students who can think critically are not only able to make decisions and solve problems, but they are also able to provide clear reasons for the decisions or solutions they provide.

Students' critical-thinking skills are still considered low, one of which is due to the lack of motivation of students to pay attention to physics learning in the classroom. The low level of criticalthinking skills of students is also indicated by the difficulty in expressing their opinions because they are not confident with the answers stated. This feeling of insecurity arises because they do not understand the material of physics, and finally they respond based on their basic knowledge. The nature of the apathy of students when learning takes place is also one of the factors not developing the ability to think critically. Learning success is related to critical-thinking skills incoherence as specialized domain knowledge requires mental thinking activities such as predicting, analyzing, synthesizing, evaluating, reasoning and so on (Tiruneh et al. 2017).

A learning model that supports the improvement of students' critical-thinking skills needs to be applied in classroom learning. Based on this, a clear stage of learning model is needed to enable students to active thinking, ask questions, discuss, and conclude a problem. The teacher can use a learning model that facilitates students to be actively involved in learning to develop critical-thinking skills. We can used cooperative learning models with Student Facilitator and Explaining (SFAE) type. The SFAE learning model is a model involves the activeness of students in the learning process and invites students to learn to present ideas to other students. This SFAE cooperative learning model uses small groups with a heterogeneous number of members in each group consisting of 4-5 students in their learning (Trianto 2007).

The material chosen in this study is material momentum and impulse, it is because of several considerations, including momentum and impulse material has many applications in daily life and is still considered difficult by students. Besides, based on previous research (Suryani 2013) revealed that the critical-thinking skills possessed by students in momentum material and impulses were still low. It is because of the limited skills of students to form and find other alternatives to solve problems, the difficulty of students in concluding, and students tend to lack understanding of the concept when working on the problem.

Several previous studies on the application of the SFAE type cooperative learning model, including the application of the SFAE model can improve student learning achievement (Novaliana et al. 2015, Christianti \& Azmi, 2014). The research is in line with the research conducted by Wati (2014) who said that the SFAE learning model could improve the skills of opinion as well as student achievement. Research conducted by Zain (2013) and Nirsam et al. (2013) revealed that the SFAE learning model was strongly recommended to be used as a learning innovation because it can improve student learning outcomes. Research by Rianti \& Nulhakim (2017) and Mawarsih et al. (2014) shows that the SFAE learning model can improve students' conceptual understanding. The SFAE learning model is effective in increasing student activity and learning achievement (Ariani 2013). Furthermore, the SFAE learning model can improve students' critical-thinking skills and 
problem-solving skills (Muslim 2014). Based on the results of previous studies, the SFAE learning model can improve learning achievement, learning outcomes, understanding concepts, learning activities, critical-thinking skills, and student problem-solving skills. The difference between previous research and novelties from this study is that the SFAE learning model is integrated with laboratory activities that are expected to improve students' critical-thinking skills of the concept of momentum and impulse.

\section{RESEARCH METHODOLOGY}

\section{Research Design}

The research method used was an experimental method with one-group pre-experimental pretestposttest type design. This research was conducted in one group of students (experimental group) without any comparison group (control group). The researcher made the initial measurement (pretest) of students' critical-thinking skills, then gave the treatment in the form of applying the SFAE model. The stages of the SFAE model include: 1) conveying the competencies to be achieved, 2) demonstrating/presenting material, 3) presenting, 4) concluding ideas, 5) explaining the material that has been delivered, 6) closing and evaluation (Suprijono 2009). The stage of delivering competencies, the teacher explains the learning objectives, conveys a summary of the contents and links with the bigger picture of the syllabus. The demonstration stage and presenting the material, the teacher demonstrates the material to be practiced, and students pay attention. The teacher divides students into several groups heterogeneously. The teacher explains to students how to design and practice. Students are asked to do a practicum and record what they already know is related to material momentum indicators and impulses. The teacher asks students to exchange ideas during practical work, so they are more confident. In the presentation stage, the teacher gives an opportunity for students to explain to other students, for example, the results and analysis of the practicum that has been done. The stage of concluding the idea, the teacher at this stage concludes the results of the discussion that has been done by the students. The stage of explaining the material, the teacher at this stage gives reinforcement and realigns the students' perceptions based on the present results that have been presented. The closing and evaluation stages, the teacher at this stage provides evaluation questions as an exercise for students. The implementation of the SFAE model is measured using an observation sheet filled in by the observer. The data obtained are then analyzed quantitatively and qualitatively based on observations. The material discussed in this study is momentum and impulse with the submersion of momentum and impulses, the coefficient of restitution, and the law of conservation of momentum. The data obtained were then analyzed and interpreted to determine the achievement of student scores. After being given treatment of the SFAE model, the researchers made measurements again of students' critical-thinking skills (posttest).

\section{Participant}

The population of this study is class X MIA SMA YAS Bandung 2017/2018 school year, which consists of two classes with a total of 68 students. The sample of this study was class X MIA 2, which amounted to 30 students selected using a simple random sampling technique.

\section{Research Data}

The data in this study were obtained from observation sheet instruments, student worksheets, and critical-thinking tests. The observation sheet was used to obtain the implementation data of the SFAE model obtained through observations made by the observers during the learning activities. The observation sheet uses a Likert scale as the rating scale. Student worksheets are supporting instruments used at each meeting to train students' critical-thinking skills. The critical-thinking tests used amounted to seven essay questions that were used to determine the achievement of indicators of students' critical-thinking skills and the significance of their improvement. Indicators of criticalthinking skills of students who are trained and developed included interpreting, analyzing, synthesizing, inferring, explaining, and evaluating (Binkley et al. 2012). Each question of critical- 
thinking skills is tested first and analyzed quantitative. These tests include validity, reliability, distinguishing power, and the level of difficulty through calculation.

\section{Data Analysis}

Analysis of the observation sheet data was done by calculating the percentage of the implementation of the SFAE type cooperative learning. The results of the analysis are then interpreted using the learning implementation criteria according to Purwanto (2009) shown in TABLE 1.

TABLE 1. Criteria for implementation SFAE model learning

\begin{tabular}{ll}
\hline Value Range & Criteria \\
\hline$\leq 54 \%$ & Very Less \\
$55 \%-59 \%$ & Less \\
$60 \%-75 \%$ & Medium \\
$76 \%-85 \%$ & Good \\
$86 \%-100 \%$ & Very Good \\
\hline
\end{tabular}

The implementation of learning was analyzed qualitatively based on the results of observer comments on the observation sheet that observed the activities of teachers and students during the SFAE cooperative learning model applied.

Analysis of student worksheet data was done by calculating the percentage of student answers and interpreted to find out the achievement of scores of students' critical-thinking skills. Student worksheets are given in each lesson with the SFAE model three times. The criteria for achieving the scores of students' critical-thinking skills refer to the opinion of Arikunto (2012) shown in TABLE 2.

TABLE 2. Criteria for student achievement

\begin{tabular}{ll}
\hline Score & Interpretation \\
\hline $30-40$ & Failed \\
$40-55$ & Less \\
$56-65$ & Enough \\
$66-79$ & Good \\
$80-100$ & Very Good \\
\hline
\end{tabular}

The improvements of critical-thinking skills were analyzed based on the results of the students' pretest and posttest. The normalized gain $\langle\mathrm{g}\rangle$ values obtained then interpreted according to the criteria according to Hake (1998) are shown in TABLE 3.

TABLE 3. Criteria for value of normalized gain $\langle\mathrm{g}\rangle$

\begin{tabular}{cl}
\hline Value of normalized gain $\langle\mathrm{g}\rangle$ & Criteria \\
\hline$(<\mathrm{g}>)<0,3$ & Low \\
$0,7>(\langle\mathrm{g}>)>0,3$ & Medium \\
$(<\mathrm{g}\rangle)>0,7$ & High \\
\hline
\end{tabular}

The normality test and hypothesis test do the procedure adopted in hypothesis testing. The normality test is carried out by using the Liliefors test with a significance level $(\alpha)$ of $5 \%$. Then test the hypothesis using paired sample t-test for normally distributed data and the Wilcoxon test for data that are abnormally distributed with $\alpha$ of $5 \%$. 


\section{RESULTS AND DISCUSSION}

\section{Implementation of SFAE Model Learning}

The application of the SFAE type cooperative learning model is a treatment given to improve students' critical-thinking skills in material momentum and impulses. The treatment was given three times. The results of the observation sheet analysis on the average implementation of teacher and student activities at each stage of the SFAE model as a whole can be seen in TABLE 4.

TABLE 4. Analysis of the implementation of SFAE model with an observation sheet

\begin{tabular}{llcccc}
\hline \multirow{2}{*}{ No. } & The phase of SFAE & \multicolumn{4}{c}{ The average percentage of implementation } \\
\cline { 2 - 5 } & model & Teacher activity $(\%)$ & Criteria & Student activity $(\%)$ & Criteria \\
\hline 1 & Introduction & 82 & Good & 80 & Good \\
2 & Delivering competence & 82 & Good & 80 & Good \\
3 & Demonstrating & 81 & Good & 81 & Medium \\
4 & Presenting & 75 & Medium & 70 & Medium \\
5 & Concluding & 80 & Good & 78 & Good \\
6 & Explaining material & 84 & Good & 73 & Good \\
7 & Closing & 82 & Good & 80 & Good \\
\hline & Average & 81 & Good & 77 & Good \\
\hline
\end{tabular}

The average percentage of teacher activity implementation is $81 \%$ including good criteria and student activities at $77 \%$ including good criteria. The stage of explaining the material on teacher activities is included in the highest criteria with the percentage of implementation being $84 \%$ including the criteria for good. The lowest teacher activity occurs at the present stage of $75 \%$ including the medium criteria. The highest stage in student activity occurs at the demonstration stage of $81 \%$ including the criteria of good. The lowest student activity is the same as teacher activity occurs at the presentation stage by $70 \%$ including the criteria for being.

The presentation is the lowest stage in the activities of teachers and students. Students at the presentation stage are required to be able to convey the material they have learned and do with the group. The reason for the low stage of presentation is because students lack the confidence to present the results of group discussions, and the teacher is forced to ask several students to come forward with a presentation. Students who pay less attention to the teacher's explanation cause them to lack confidence in understanding the material, so students are reluctant to present. It is by the statement of Utami \& Naryatmojo (2016) that the usual weakness when making presentations is that the presenter (students) is hesitant and lacks confidence in delivering the material because the presenter (student) has not mastered the material to be presented.

The teacher's activity with the highest score is based on the average results of the analysis of each meeting at the stage of explaining the material. That is because the teacher is accustomed to explaining the material in front of the class and can attract students' attention to understand the material being studied. The opinion of Kustijono (2011) the skills of teachers in explaining the material determines the level of understanding of students. The demonstration stage is the highest stage that occurs in student activities. Students at this stage in addition to paying attention to the demonstrations conducted by the teacher also do activity laboratory in groups. The SFAE learning model provides opportunities for students to be actively involved in learning both individually and in groups (Suprijono 2009).

Based on observations made by observers on the implementation of the SFAE model, this model can directly involve students as facilitators for other students so that they can improve students' critical-thinking skills. The strength of the SFAE model is that it can broaden the horizons of students through activities to exchange information, opinions, and experiences and encourage the growth and development of students' critical-thinking potential optimally. Prasetya (2015) said that the SFAE learning model had the advantages of being able to train students to be active, creative and critical in dealing with every problem. Also, it can increase students' ability to exchange opinions objectively and rationally to find the truth in group member cooperation. In addition to the advantages that have 
been mentioned, the SFAE learning model also has the disadvantage that students rely on each other, students who are lazy give up part of their work to active students and lazy students remain passive in their groups. Students who are lazy do not want to discuss and presentations because they feel they cannot or are embarrassed. The SFAE model has a weakness that is individual judgment is difficult because it is hidden behind the group and if there is negative competition, the results of the work are not satisfactory so that the group's efforts can be categorized as failed (Prasetya 2015).

\section{Student's Critical-Thinking Skills (CTS)}

The results of the analysis of student worksheets to train students' critical-thinking skills can be seen in TABLE 5.

TABLE 5. Analysis of the critical-thinking skills of students with an observation sheet

\begin{tabular}{llll}
\hline No. & An indicator of critical-thinking skills & Average & Interpretation \\
\hline 1 & Interpreting & 63.3 & Enough \\
2 & Analyzing & 65.5 & Enough \\
3 & Inference & 70.3 & Good \\
4 & Synthesize & 56.3 & Enough \\
5 & Explaining & 71.6 & Good \\
6 & Evaluating & 61.3 & Enough \\
\hline & & 64.7 & Enough \\
\hline
\end{tabular}

Based on the results of the analysis of the student worksheet as a whole the average criticalthinking skill of students amounted to 64.7 including sufficient categories. The average indicator of the highest critical-thinking skills occurs in the indicator explaining that 71.6 are included in the good category while the lowest in the synthesizing indicator is 56.3 including the sufficient category.

The improvement students' critical-thinking skill (CTS) on each indicator based on the test results is shown in TABLE 6.

TABLE 6. The value of normalized gain for each indicator of critical thinking skills

\begin{tabular}{rlcccl}
\hline No. & Indicator of CTS & Pretest & Posttest & Normalized gain & Interpretation \\
\hline 1 & Interpreting & 31 & 74 & 0.62 & Medium \\
2 & Analyzing & 33 & 75 & 0.63 & Medium \\
3 & Inference & 28 & 76 & 0.67 & Medium \\
4 & Synthesize & 25 & 68 & 0.57 & Medium \\
5 & Explaining & 34 & 79 & 0.68 & Medium \\
6 & Evaluating & 29 & 71 & 0.59 & Medium \\
\hline
\end{tabular}

Students' critical-thinking skills of each indicator have increased and are included in the criteria of being. The highest increase in the indicator explained are 0.68 included the medium criteria. The synthesizing indicator has the lowest increase of 0.57 including the medium criteria.

The highest improvement of critical-thinking skills occurred in the indicators explained. This result is based on the data from the student worksheet which shows the indicator explaining the highest results compared to the other indicators. It caused students have become accustomed to explaining the material and applying it to laboratory activities and group discussions. The results of this study reinforce previous research, learning that is integrated with practical activities can improve indicators explaining those who achieve the highest improvement compared to other indicators of critical-thinking skills (Malik et al. 2018c).

The lowest indicator of critical-thinking skills occurs in the synthesis indicator and is included in the medium category. It is because the synthesis indicator requires students to be able to associate and combine various ideas or arguments to be able to solve a problem related to material momentum and impulses. Although the synthesis indicators have been trained and developed at each meeting through student worksheets, the improvement in this indicator is still not optimal. These results 
reinforce previous research, indicators of synthesis still need to be improved compared to other indicators of critical-thinking skills (Setiawan et al. 2018).

The Increase students' critical-thinking skills at each of sub-material of momentum and impulse are shown in TABLE 7.

TABLE 7. The normalized gain value for each sub-material of momentum and impulse

\begin{tabular}{llllll}
\hline No. & \multicolumn{1}{c}{ Sub material } & Pretest & Posttest & N-Gain & Criteria \\
\hline 1 & Momentum and Impulse & 34 & 79 & 0.68 & Medium \\
2 & Restitution coefficient & 26 & 70 & 0.59 & Medium \\
3 & $\begin{array}{l}\text { Law of conservation of } \\
\text { momentum }\end{array}$ & 30 & 73 & 0.61 & Medium \\
\hline \multicolumn{2}{c}{ Average } & 30 & 74 & 0.63 & Medium \\
\hline
\end{tabular}

Students' critical-thinking skills in each sub-material of momentum and impulse increased and included the criteria of being. The highest increase in the momentum and impulse submersion of 0.68 is included in the medium criteria. Sub material for the coefficient of restitution experienced the lowest increase of 0.59 including the criteria for being.

The SFAE learning model provides opportunities for students to engage in learning and develop their thinking skills actively. This is consistent with the opinion of Suprijono (2009), the SFAE model involves students directly as facilitators for other students in improving learning outcomes. Although applied in various sub-material of momentum and impulses, the SFAE model can still improve students' critical-thinking skills. The SFAE learning model trains students to present ideas or opinions to other students through a chart/concept map related to the material being studied.

Based on the results of data analysis, there is an increase in students' critical-thinking skills on each sub-material at each meeting. Student worksheets can train and develop students' criticalthinking skills; this is because students are conditioned to learn in groups and issue ideas, both in the form of questions and answers to be able to solve a problem. Komaria (2015) suggests that the development of the right learning model aims to create learning so that students are enabled to learn actively and pleasantly. Students who are actively involved in learning show that they can learn and construct knowledge not only receive information.

Based on the results of the analysis of the pretest and posttest scores, the improvement of students critical-thinking skills can be seen through the average normalized gain $(\langle\mathrm{g}\rangle)$ values shown in TABLE 8.

TABLE 8. Improving students' critical-thinking skills

\begin{tabular}{lcccc}
\hline & Pretest & Posttest & $\begin{array}{c}\text { Normalized } \\
\text { Gain }\end{array}$ & Criteria \\
\hline Amount & 968 & 2245 & 0,63 & Medium \\
Average & 30 & 74 & & \\
\hline
\end{tabular}

There is an increase in students' critical-thinking skills after the SFAE model is applied to momentum and impulse material with an average N-Gain of 0.63 including the medium category. It can be seen from the average score on the pretest and posttest of students who have increased.

Hypothesis testing is used to determine the significance of improving students' critical-thinking skills. The procedure adopted in hypothesis testing consists of a normality test and a hypothesis test. The results of the normality test for the pretest and posttest data were carried out using the liliefors tests. The calculation results show data of Lcount pretest $(0.117)<$ Ltable $(0.161)$ with a significance level $(\alpha)$ of $5 \%$ and posttest data is known Lcount $(0.159)<$ Ltable $(0.161)$ with $\alpha$ of $5 \%$. Based on these results it can be concluded that the data is normally distributed and the hypothesis test used is paired sample t-test. Hypothesis test results show that tcount $>$ ttable with tcount $=34.8$ and ttable $=$ 2.052 for $\alpha=5 \%$, so it can be concluded that there is an effect of the application of the SFAE model on improving students' critical-thinking skills in momentum and impulse material. The improvement of students' critical-thinking skills is in line with the research conducted by Setiawan (2017) which states that the SFAE learning model can improve students' critical-thinking skills. 
Based on this research, there are limitations should be considered when making discourses and arguments for measuring students' critical-thinking skills. The discourse and the arguments presented must include limited contextual daily events. Critical thinking requires perseverance to test beliefs or ideas and search for evidence that supports these ideas to produce conclusions or appropriate actions to be decided (Gregor 2007).

\section{CONCLUSIONS}

Based on the results of the study, the implementation of the SFAE learning model at each meeting was carried out well. The percentage of implementation for teacher activities was $81 \%$ including good categories, and the percentage of student activity implementation was $77 \%$ including good categories - improvement of students' critical-thinking skills in material momentum and impulse after the implementation of the SFAE learning model, including the medium category with an average normalized gain (N-gain) of 0.63. The SFAE learning model consists of five stages in which each stage allows students to think skillfully to be trained and developed. The relationship between the stages of the SFAE model with students' critical-thinking skills in the momentum and impulse material includes 1 . The teacher's activity at the demonstration stage can train students' ability to analyze information in the background of an argument/opinion/claim. Teacher activity directs students to discuss with their group friends to discuss the advantages and disadvantages of solutions or conclusions to be taken can train the ability of interpretation to determine the meaning of an arguments/opinions/claims accordingly, the ability to synthesize to link information with arguments/opinions/claims which is relevant, ability to explain to raise clarification questions related to the arguments/opinions/claims that are appropriate and the ability to evaluate to express the strengths and weaknesses of ideas/arguments related to solving a problem. The teacher's activity concludes the ideas/opinions of students can train their ability to make conclusions appropriately according to the context of the problem that must be resolved. Students' critical-thinking skills in synthesizing indicators need to be optimally improved one of the ways students are trained to be skillful at combine various related concepts to be competent to solve a contextual problem.

\section{REFERENCES}

Ariani, D 2013, 'Keefektifan Penerapan Model Pembelajaran Student Facilitator and Explaining terhadap Aktivitas dan Prestasi Belajar Siswa Kelas XI Semester 2 SMA Negeri 1 Muntilan Tahun Ajaran 2012/2013', Doktor Disertasi, Universitas Negeri Yogyakarta.

Arikunto, S 2012, Dasar-Dasar Evaluasi Pendidikan, Bumi Aksara, Jakarta.

Bassam, G 2008, Critical Thinking Fourth Edition, Mc Graw-Hill, New York.

Binkley, M, Erstad, O, Herman, J, Raizen, S, Ripley, M, Miller-Ricci, M \& Rumble M 2012, Defining Twenty-First Century Skills (Assessment and Teaching of 21 st Century Skills), Springer, New York.

Christianti, H \& Azmi, J 2014, 'Penerapan model pembelajaran kooperatif tipe student facilitator and explaining (SFAE) untuk meningkatkan prestasi belajar siswa pada pokok bahasan kimia koloid di kelas XI IPA SMA Santa Maria Pekanbaru', Jurnal Pendidikan Kimia, vol. 6, no. 2, pp. 81-85.

Gregor, M 2007, Developing Thinking Developing Learning: A Guide to Thinking Skills in Education, Mc Graw-Hill, New York.

Hake, RR 1998, 'Interactive-Engagement Versus Traditional Methods: A Six-Thousand-Student Survey of Mechanics Test Data for Introductory Physics Courses,' American Journal of Physics, vol. 66, pp. 64-67.

Helpern, DF 2014, Thought and Knowledge: An Introduction to Critical Thinking (5th Ed.), Psychology Press, New York. 
Komaria, ATND, Siswandari \& Ivada, E 2015, 'Penerapan Strategi Pembelajaran Aktif Learning Start with A Question sebagai Upaya untuk Meningkatkan Keaktifan Siswa Mata Pelajaran Akuntansi Keuangan', Tata Arta, vol. 1, no. 2, pp. 223-236.

Kustijono, R 2011, 'Implementasi Student Centered Learning dalam Praktikum Fisika Dasar', Jurnal Penelitian Fisika dan Aplikasinya (JPFA), vol. 1, no. 2, pp. 19-23.

Malik, A, Setiawan, A, Suhandi, A, Permanasari, A \& Heminta, N 2018b, 'The Effect of HOT-Lab to Improve Critical Thinking Skills of Prospective Physics Teachers', Advanced Science Letters, vol. 24, no. 11, pp. 8059-8062.

Malik, A, Setiawan, A, Suhandi, A, Permanasari, A, Dirgantara, Y, Yuniarti, H, Sapriadil \& Heminta, N 2018a, 'Enhancing Communication Skills of Pre-Service Physics Teacher Through HOT Lab Related to Electric Circuit,' J. Phys.: Conf. Ser. vol. 953, no. 1, p. 012017

Malik, A, Setiawan, A, Suhandi, A, Permanasari, A, Samsudin, A, Safitri, D, Lisdiani, SAS, Sapriadil \& Hermita, N 2018c, 'Using HOT Lab to Increase Pre-Service Physics Teacher's Critical Thinking Skills Related to The Topic of RLC Circuit,' J. Phys. Conf. Ser., vol. 1013, no. 1, p. 012023.

Mawarsih, M, Syamsu, S \& Kamaluddin, H 2014, 'Penerapan Model Pembelajaran Kooperatif Student Facilitator and Explaining untuk Meningkatkan Pemahaman Konsep Fisika pada Siswa Kelas X SMA Negeri 5 Palu', Jurnal Pendidikan Fisika Tadulako Online (JPFT), vol. 4, no. 3, pp. 16-21.

Muslim, SR 2014, 'Pengaruh Penggunaan Metode Student Facilitator and Explaining dalam Pembelajaran Kooperatif terhadap Kemampuan Pemecahan Masalah Matematik dan Kemampuan Berpikir Kritis Matematik Siswa SMK di Kota Tasikmalaya', Jurnal Pendidikan dan Keguruan, vol. 1, no. 1, pp. 11-20.

Nirsam, Ali, M \& Kamaluddin 2013, 'Meningkatkan Hasil Belajar Fisika Melalui Penerapan Model Pembelajaran Kooperatif Tipe Student Facilitator and Explaining (SFAE) pada Siswa Kelas VIII SMP Negeri 5 Palu', Jurnal Pendidikan Fisika Tadulako, vol. 1, no. 6.

Novaliana, Susilawati \& Erviyenny 2015, 'Implementation of Cooperative Learning Model Type Student Facilitator and Explaining (SFE) to Increase Student Learning Achievement on The Subject of The Structure of Atoms and The Periodic System of Elements In Class XI Science SMAN 1 Kateman Inhil', Pen, vol. 4, no. 1, pp. 1-14.

Prasetya, JT 2015, Strategi belajar mengajar, Pustaka Setia, Bandung.

Purwanto, NM 2009, Prinsip-prinsip dan teknik evaluasi pengajaran, Remaja Rosda Karya, Bandung.

Rianti, L \& Nulhakim, L 2017, 'Pengaruh Model Student Facilitator and Explaining (SFAE) terhadap Pemahaman Konsep Siswa Kelas IV pada Mata Pelajaran IPA', Jurnal Pendidikan Sekolah Dasar, vol. 3, no. 1, pp. 64-73.

Rotherham, AJ \& Williangham, D 2009, '21st Century Skills: The Challenges Ahead', Educational Leadership, vol. 67, no. 1, pp. 16-21.

Setiawan, A, Malik, A, Suhandi, A \& Permanasari, A 2018, 'Effect of Higher Order Thinking Laboratory on The Improvement of Critical and Creative Thinking Skills,' IOP Conf. Ser.: Mater. Sci. Eng. vol 306, no. 012008.

Setiawan, MA 2017, 'Pengaruh Model Pembelajaran Problem Based Learning Dipadu Student Facilitator and Explaining terhadap Kemampuan Berpikir Kritis Siswa Kelas X SMAN 6 Kediri Pada Pokok Bahasan Fungi', Florea: Jurnal Biologi dan Pembelajarannya, vol. 4, no. 1, pp. 1-4.

Suprijono 2009, Cooperative Learning (Teori \& Aplikasi PAIKEM), Pustaka Pelajar, Yogyakarta.

Suryani, I 2013, 'Keterampilan Berpikir Kritis Siswa dalam Menyelesaikan Soal Fisika tentang Impuls dan Momentum', Jurnal Pendidikan Fisika, vol. 4, no. 2, pp. 1-8. 
Tiruneh, DT, De Cock, M, Weldeslassie, AG, Elen, J \& Janssen, R 2017, 'Measuring Critical Thinking in Physics: Development and Validation of A Critical Thinking Test in Electricity and Magnetism', Int J of Sci and Math Educ, vol. 15, no.4, pp. 663-682.

Trianto 2007, Model-model pembelajaran inovatif berorientasi konstruktivistik, Prestasi Pustaka, Jakarta.

Trilling B \& Fadel C 2009, 21st Century Skills: Learning for Life in Our Times, Jossey-Bass A Wiley Imprint, San Francisco.

Utami, SPT \& Naryatmojo, DL 2016, 'Pelatihan Presentasi Ilmiah untuk Meningkatkan Daya Saing dalam Kompetisi Ilmiah Bagi Anggota Ekstrakurikuler Karya Ilmiah Remaja di Kota Semarang', Semar, vol. 5, no. 1, pp. 83-91.

Wati, FI 2014, 'Penerapan Model Pembelajaran Student Facilitator and Explaining (SFAE) untuk Meningkatkan Kemampuan Berpendapat dan Prestasi Belajar Fisika Siswa Kelas XI-IPA 1 SMA Negeri 1 Kalidawir Tulungagung', Jurnal Pendidikan Fisika, vol. 1, no. 2, pp. 25-31.

Zain, ARR 2013, 'Pengaruh Model Pembelajaran Kooperatif Tipe Student Facilitator and Explaining (SFAE) Terhadap Hasil Belajar Siswa pada Standar Kompetensi Menafsirkan Gambar Teknik Listrik SMKN 2 Pamekasan', Jurnal Pendidikan Teknik Elektro, vol. 1, no. 2, pp. 12-16.

Zohar, A 2013, 'Challenges in Wide Scale Implementation Efforts to Foster Higher Order Thinking (HOT) in Science Education Across A Whole School System,' Thinking Skills and Creativity, vol. 10, pp. 233-249. 